\title{
METHODS AND TECHNOLOGIES SUPPORTING INFORMATION AND KNOWLEDGE MANAGEMENT ON THE EXAMPLE OF THE POLICE
}

\author{
Agnieszka SZCZYGIELSKA
}

Institute of Management, Management and Command Faculty, Warsaw, Poland e-mail: a.szczygielska@aon.edu.pl

\begin{abstract}
This work refers to one of the hierarchical organizations, which is the police. The example of the Municipal Crowd Management (Stoteczne Stanowisko Kierowania; SSK) has been chosen as the basis for a detailed analysis presented in this article. The Department, as the place where the work of many individuals, departments and services is integrated, must demonstrate a high level of knowledge, competence, and coordination activities. The innovative technologies appear to be the unquestionable support. They should primarily serve the needs of managing knowledge on the efficient actions in relation to the socio-market requirements. In case of this organization, these solutions play a vital part in the creation of intelligent organization to support its activities focused on delivering effective public services and thus contributing to build the knowledge economy in Poland. An attempt to present the discussed issues has been taken in this study.
\end{abstract}

Keywords: hierarchical organizations, knowledge management, high-technology, the police, police management.

\section{Introduction}

Modern management imposes new requirements on the executives and public authorities. They often refer to deep foundations and basic philosophy of their actions, but often the base of what is already fixed turns out to be the most difficult to change. Conditions of these requirements can be summarized as the following demands:

- prevention of the emergence of problems instead of solving them (understood as a diagnosis rather than treatment),

- supporting the citizens of the state in solving problems (the desire to help and give advice),

- creating opportunities and the opportunity for success,

- openness to new technologies, ideas, and management methods.

In a knowledge-based economy where speed of response is important, modernity of applied solutions and accuracy of decisions, an integral and natural part of daily management becomes innovation.

It should be remembered that there is a very strong relationship and mutual influence between innovation and knowledge. Innovation is a kind of transformed knowledge, modified, revised, useful, sometimes formally approved and finally implemented in practice.

Innovation undoubtedly involves expanding the range of knowledge in the organization, especially if the source of this knowledge is external and not internal. Such situation requires more organizational activity associated with learning and absorbing new quality of knowledge or even updating and verifying the already acquired knowledge. A company whose innovation has an impact on the actual real activities, depends primarily on the people, the desire to use their intellectual potential, creativity, commitment to the objectives of the institution, and the flexibility to change.

The main objective of this paper is to highlight the role of information and knowledge management in public organizations in Poland, with particular emphasis on hierarchical organizations, at this point the police. The intention of the author is an attempt to approximate knowledge management issues by quoting practical activities carried out in the public sector. The intention is also to show the selected elements of this concept in the Municipal Crowd Management and their impact on improving the effectiveness and efficiency of these services. 


\section{The essence of knowledge management in public organizations in the knowledge economy}

Currently, in any organization, and especially in those that have adopted the goal of serving the society, providing a sense of security and taking care of the everyday life, we came "(...) to deal with a very difficult opponent: ourselves. Who is able in time to see that solutions developed so recently and so hard again require a change? Who voluntarily chooses to put question mark at its greatest successes and announce the need to seek new answers to the challenges of the future? Who would be happy to take up the demolition work of their own hands?" [5, p. 151].

Rapid development of modern technology and the growing needs of society seems to be the only reasonable option, and not just for market, manufacturing, or service companies, but also for the public institutions. The ultimate goal of these actions is to create a modern state corresponding to the requirements of the knowledge-based economy and the persistent further changes in the world as well as to build a coherent network of public services to provide an efficient safe state for the benefit and satisfaction of its citizens. Building on these assumptions, it is impossible to accomplish this apart from the issue of raising awareness about the role of information and knowledge in all forms of state functioning and the ability to manage these resources. This, in turn, is linked inextricably with the attitude of pro-innovative, open technology and the use of all available upgrades in the performance of work. It is clearly emphasized by D. Snowden of IBM saying that "knowledge management is to assist decision-making processes and creating a context for innovation; nothing else matters." [9, p. 8]

The implementation of these conditions and demands is to serve the concept of an intelligent organization, where there are often objections on the possibility of its implementation in public organizations. We must bear in mind that none of the contemporary concepts will be possible to implement in its pure form in every organization, as each one has a different specificity and culture activities. It is important for each of the novel concept of effective management to make an attempt on the introduction of the key distinguishing marks of a concept to serve and support implementation of its goals in the consolidated form. "Intelligent organization is primarily a community of professionals well understand each other, partners in creative action, capable of continuous transformation of products, processes, structures and themselves in an effort to meet the requirements of the market and the challenges formulated by society." [12, p. 19] In the intelligent organization, we can discern different levels and types of knowledge; the executive level can recognize, which knowledge resources form the so-called tacit knowledge (also, tacit knowing) and which form explicit knowledge, defined by others as an expressible or available. Managerial level is also able to determine in relation to specific individuals, which knowledge is in the form of a personalized, explicit, and/or tacit, and which is in the form of codified knowledge. A good manager and leader is able to locate it, follow, at least some of it to personalize, translate into the language of signs, and make available to a wider audience stuff.

During the identification of individual intellectual resources and the dependencies remaining between them and establishing the blockages and breakpoints, an effective manager of a knowledge-based organization and manifesting the characteristics of an intelligent organization, can influence through all sorts of activities to increase the effective functioning of the group or the entire organization. The leader takes on the activity in the area of knowledge management and development of intangible assets. Many of these activities can be defined as "an effective learning process associated with the exploration, exploitation, and dissemination of knowledge (explicit and tacit), using appropriate technologies and cultural environment, which aims to increase the intellectual capital and the efficiency of the organization." [7, pp. 27-28].

In an organization such as the police, it is difficult to implement the requirements of a specific and strict knowledge management model and the precision to act in accordance with its guidelines as it has previously been mentioned in case of the implementation of the intelligent organization model. It should be remembered that knowledge management can be seen in the daily activities as well as through conscious realization of the fundamental processes supporting various activities. This applies to the activities shown in the Fig. 1 [15]. 


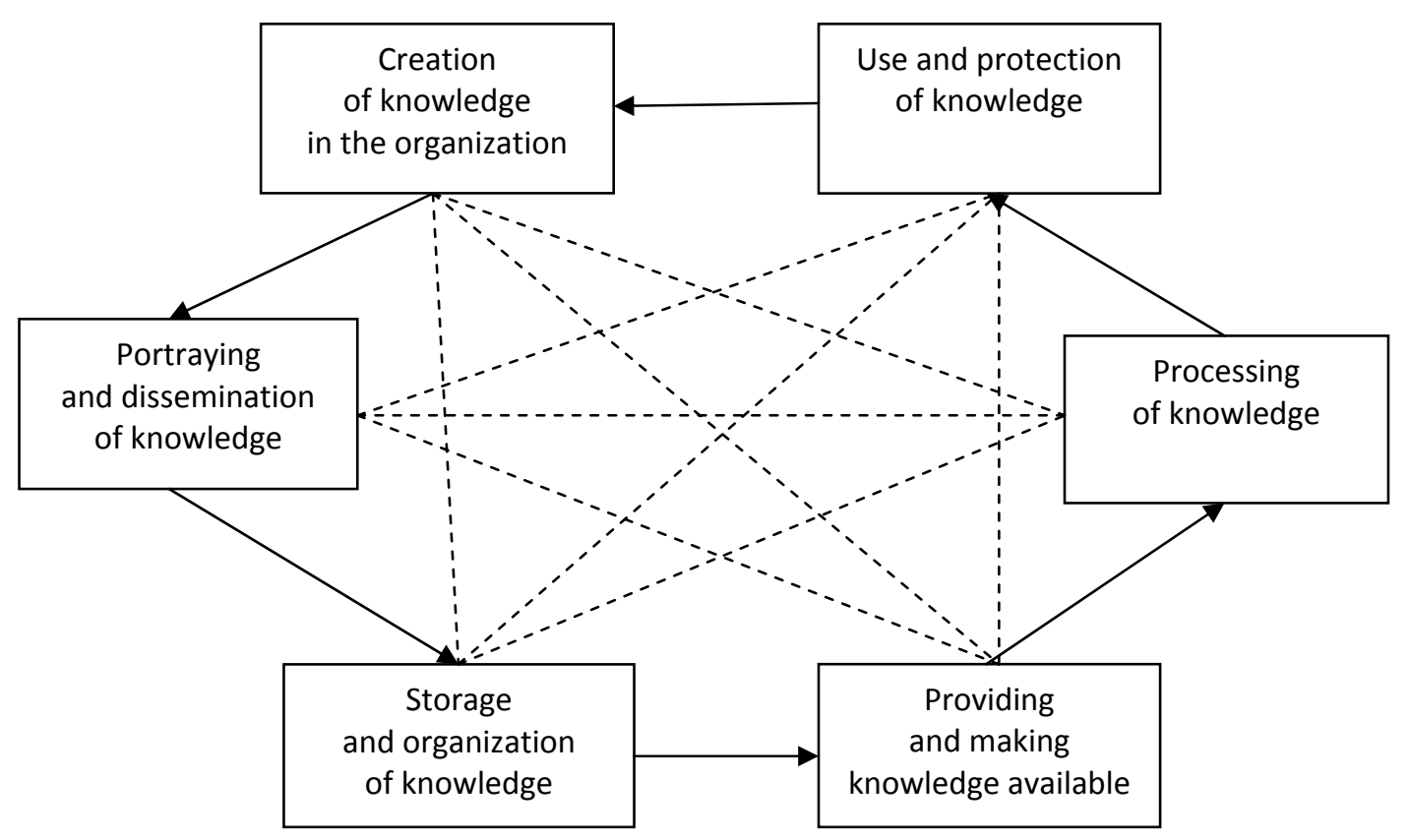

Figure 1. Fundamental processes of knowledge management (source [15])

It is also important, especially in the case of the police, to adapt to what is imposed by the present. This reality is well illustrated by a quotation, made in the U.S., which should be introduced in the way of thinking of Polish units: "To win the war against terrorism, we have to think like a street gang, move like a soccer team, and communicate like Wal-Mart." [see also: 21] Distributed by a legitimate business philosophy, it reminds us that to be effective you must draw inspiration and benchmarking against best practices and constantly update knowledge. Prior to the establishment of these imperfections and the need for continuous improvement, it should be repeated like a mantra in daily functioning and applied to practice. The introduced culture of learning and creativity imbued with courage to predict tomorrow proves to be very valuable.

The organizational culture in the police is a bit different from the traditional institutions that often have very differing cultures, even in hierarchical institutions, and despite strong legislation, the implementation of fundamental values at the level of workers' mentality is really possible. It seems that in the context of knowledge management, they should refer to continuous learning and personal mastery [See for example: 20], obtaining information and knowledge from all available sources, importance of teamwork, the need of the most profound knowing of the other side (that is, at this point, people who present a very real threat to society and the state, to be able to anticipate their pos- sible decisions and movements, and in the absence of such opportunities to have wide experience facilities) and the development of systems thinking skills. The value of innovative and conscious use of all availed facilities, persistent search for many more opportunities for improvement, and ultimately the awareness that at any moment you can achieve something even more perfect than the status quo, must be also recognized.

The police should have undeniably the most modern technological facilities for gaining information to support learning and the creation of new knowledge. Resources management as well as the creation of the whole intellectual capital should be considered here as complementary, interdependent, and overlapping processes, because intellectual capital is derived and is the result of skillful use of knowledge in practice [23].

The widespread use of modern information technology is noted not only in highly developed countries. Sanjay Sahay, Inspector-General of Police, Eastern Division (Davangere) in India, said police personnel should concentrate on improving their knowledge of technolo$\mathrm{gy}^{1}$, as cyber crimes are increasing. He added that the

1 It is worth mentioning that the Higher Police School in Szczytno has already held three conferences on Modern Technologies in Security and Public Order (NTSPO). They were devoted exclusively to the role of modern technology in security 
awareness among police personnel about the latest technologies will play a key role in preventing crimes. It is worth noting that in such a small town and country where technological development is not considered as being at the highest world level, the importance of the role of these technologies and knowledge resources in the development of secure state is recognized and valued [24].

A great emphasis placed on the need for education and continuous improvement of officers in the units of the Polish Police Service may arise partly from a noticeable tremendous progress and rapid access to information and the use of it for criminal purposes by various individuals and groups. In recent months, for example, the need for training in the field of combating economic crime (its range is covered by more than 100 legal acts) in connection with uninterrupted socio-economic changes and cunning ability to find loopholes by persons involved in numerous business processes and pseudo-business has been raised. According to J. Zarzycki ${ }^{2}$, the training in the prevention of economic crime is “(...) necessary not only for new applicants but also for the old pros perfecting their skills. (...) The officers involved in the fight against economic crime, apart from specialized knowledge, should be primarily open to every form of general knowledge." [26, pp.11].

Keeping abreast with current technological changes should be very essential for police executives because today's managers must not only be fully aware of the development of modern technology but also have knowledge about what this technology might perform in their institutions, faculties, individuals or groups. The managers should also have the ability to acquire technology through a variety of funding sources. It is obvious that employees prefer having outstanding and innovative equipment that by the very fact of its possible use at work can affect raising their morale and motivate to work more efficiently and be more involved [see also: 22]. It also increases their sense of security and professional skills.

and public order, training programs and professional development; an attempt was made to introduce these educational concepts at the managerial level and research has been directed at the implementation of these issues.

${ }^{2}$ Junior Insp. Jaroslaw Zarzycki serves as head of the Department of Crime Combating Economic Crime Bureau of the Police Headquarters.
It should also be emphasized that, in spite of available modern technologies and additionally employed experienced employees, the strict regulations prevent the pragmatics of modern systems from implementing to practice, which leads to ineffective uses of their capabilities. Thus, there is a situation when experienced people and IT facilities are availed but are followed by legislative blockade. For example, the DNA laboratory in the Biology Department of Central Forensic Laboratory of the Police equipped with innovative devices on a global level uses the services of eminent specialists in this field but, unfortunately, the regulations greatly restrict the access to the equipment. This refers to the collection and storage of personal data by the police. Such a policy significantly reduced the chance of obtaining material bases and made (described further below) Automated Fingerprint Identification System (AFIS) database full of loopholes and, in fact, more useless tool than expected [13, pp.13]. This situation is regrettably extremely frustrating with its overtones of helplessness and lack of influence on the change in the near future.

Searching for effective management solutions and attempts to implement interesting applications cannot be forgotten that in the first place, it is necessary to change the role of knowledge awareness, speed of obtaining information, and the use of all technological facilities for the benefit of society. This does not apply only to officers, employees of uniformed services but also to individuals cooperating with said services, legal and regulatory institutions. It is intended that the final should be sought, if the law actually protects and is not a real barrier for citizens in the process of truth creating another stopping points, building artificial walls to shield misty suspected social interests.

\section{The Crowd Control Department of the Met- ropolitan Police Headquarters Knowledge Management}

The basis of presented issues and practical aspects of the concept of knowledge management in the Municipal Crowd Management Department of the Metropolitan Police Headquarters is open. It was complemented by the author of selected information technological solutions during daily work and observation of work in the section on duty. Collecting information is supplementary in-depth by telephone calls. 


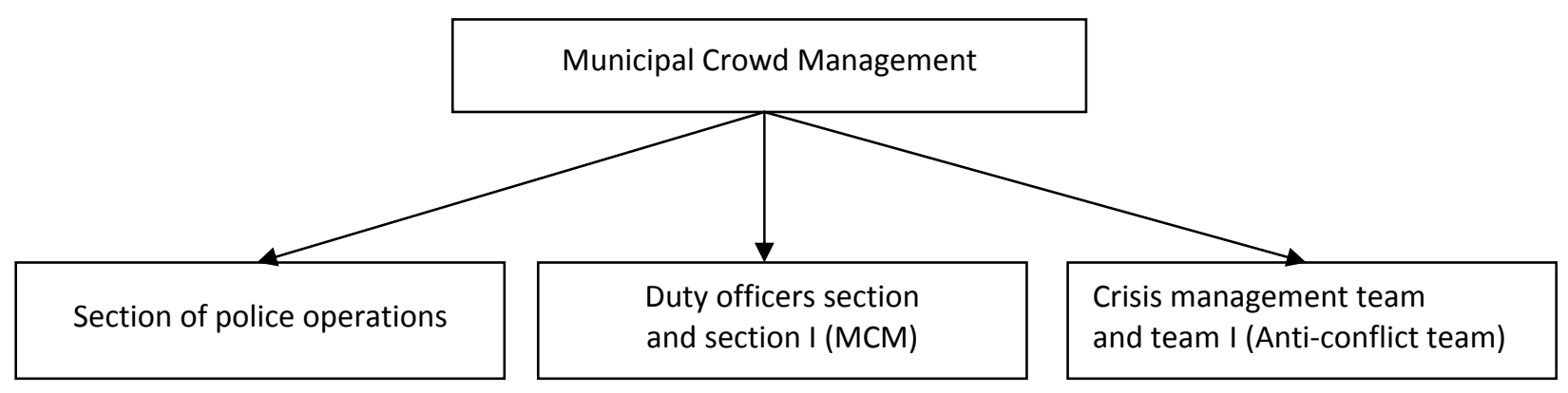

Figure 2. Municipal Crowd Management and its sections (source: own work)

The interview was conducted with the person working actively in the SSK. The research was qualitative in nature, referring in tone, and discussed aspects of the pillars of the concept of knowledge management.

Personal observations made by the author in the Municipal Crowd Management allowed largely to confirm the information obtained during the interview and perceive further opportunities for growth, expansion, and list numerous sectors where additional assistance would be needed in order to further improve the performance of their tasks and thereby increase the efficiency of work for the society.

In order to justify further comments and proposals made by the author, it should be borne in mind that the Municipal Crowd Management is a department of Metropolitan Police Service running its tasks through specific sections and teams as shown in Fig. 2.

Looking at the work of this department, it may be noted that it combines and coordinates the role and responsibility of multiple units while working closely with other public services, such as fire department, military, and health care. The degree of procedural order work must therefore be at the highest level, which means that the Municipal Crowd Management is an even more complex task to be performed. Technological solutions applied in this unit primarily refer to the information and coordination technologies in supporting management of information and knowledge resources as well as techniques to organize a knowledge-base in such a way as to ensure the safety of citizens, for example, in the case of mass events, state celebrations, or public gatherings. For this reason, all of these activities and solutions are of particular importance for described unit operating in the capital. Municipal Crowd Management through its actions somehow would be an example how to integrate and connect with other departments and in addition, supervises and divides the tasks. Just as the activities of the appointed head of the organization set some patterns and models of behavior, the Municipal Crowd Management department is regarded by others as a point of relevance in terms of different actions and inspiration for further achievements.

With respect to individual knowledge management processes [18], it seems necessary to organize a set of internal seminars in the near future offering trainings in different areas. Within the following categories, a seminar program should be continuously developed on issues relevant to the specialization of individuals or groups, highlighting the valuable role of mentoring and inspiring coaching. Training sessions should be conducted by experienced staff or invited experts. This would facilitate the acquisition and better flow of knowledge as well as contribute towards drastic reduction of bureaucracy and the degree of stiffness in mechanistic organizational structure of the Police, which is recognized by the staff as one of the essential elements blocking their growth and the undertaken actions less efficient [11]. The implementation of knowledge transfer session would be also valuable that would involve structured meetings devoted to the exchange of knowledge, for example, between individuals from different organizational units. Therefore, extremely valuable is people talent management, providing training and concern about interpersonal relationships in the workplace, and encouraging the sharing of their knowledge. Undoubtedly, cooperation in a virtual $S P A C E$ in disseminating knowledge could become more convenient, for example, computer programs to help those involved in the project to remotely interact and ultimately achieve the objectives of the team. 
The base-knowledge and data warehouses seem to be helpful and fundamental to knowledge management in this institution [16]. In the event of any undertaken action, the access to a variety of data on individuals, groups, and ongoing projects is most important. In addition, it is noteworthy that the databases should contain already developed and released cases, best practices, serving as a support and inspiration.

Command Support System (System Wspomagania Dowodzenia) $)^{3}$ is an extremely powerful technology platform that solves common operational problem for emergency commanders operating at the Municipal Crowd Management department. It has been implemented in the Police in 2012 and successfully works across a wide variety of actions. The Command Support System delivers robust functionality, including [19]:

- supporting duty services in decision-making, allocation of manpower and resources,

- ensuring police response time on the received notification,

- increasing the efficiency of police work,

- ensuring regular access to information for all duty service, prevention forces, and traffic service,

- automation of the activities through the introduction of electronic registration of entries,

- providing mobile access to system resources,

- unification method of documenting activities.

The Command Support System works across a wide variety of databases held by the police. Integrates and facilitates interoperability between: duty officers of Municipal Police and other public safety dispatchers, transport dispatchers, duty officers of the county police stations, pedestrians and motorized patrols, and the prevention forces. In addition, significantly, the internal algorithm system independently performs gradation orders. There is a constant work to enhance collaboration in the system network as well as develop an interface integrating the Command Support System with the

\footnotetext{
${ }^{3}$ Command Support System by WASKO is a multi-purpose platform supporting the operation of rescue coordination centers and law enforcement in such areas as receipt of notifications and event handling, processing the input information, and alerting the appropriate disposition of forces and means as well as visualization, collection and processing of data from a variety of devices and systems. Command Support System provides full support for command centers operating in one building, room and distributed to centers. See more on the website: accessed July 2013, http://www.wasko.pl.
}

Provincial Information System for Emergency Information Centers. This system is an integral part of the created Emergency Notification System which forms integrated systems of such services as the Police, State Fire Service, State Emergency Medical Services and Location and Information Platform with a Central Database (PLI CBD) system supports immediate location of a place from which a call to an emergency number was made, which was of great importance at Euro 2012 [17, p. 33].

In the case of activities that require action on a broader scale, there is an additional separate room with modern equipment and a separate point of command at disposal. A helicopter and Mobile Monitoring Center in the form of a bus equipped with cameras and specialized hardware is also always accessible, and can be successfully used as a mobile police station [see 2]. It should be emphasized that the duty officer has access to all databases of the section staff and may at any time monitor their conversation. All dispatchers are connected to the internal network and are able to draw the necessary information from base-knowledge to facilitate the appropriate response to the collected submissions and more efficient exchange of information between each other.

Another very interesting technology supporting knowledge management processes is the National Police Information System (Krajowy System Informacyjny Policji; KSIP), which has been implemented since the beginning of 2003 as the central information collection obtained by employees or officers of all police organizational units in the course of official duties. "The National Police Information System is functioning in the Police Data Transmission Network (Policyjna Sieć Transmisji Danych; PSTD) which is a separate network not connected with another external network infrastructure such as the Internet. Access to the National Police Information System is available via computers connected to the Police Data Transmission Network equipped with hardware protection precisely identifying the user." [3, 8]. The National Police Information System platform also provides access through the required permissions for user identification card to the National Crime Information Center. This system is run by the Chief of Police of the Ministry of Interior Affairs. The National Police Information System (NPIS) consists of several modules, for example, Application NPIS WWW and Application NPIS Emergency. 
The first two modules allow reading and recording of collected and processed information in the National Police Information System but NPIS Emergency application might be used in the case of breakdown or lack of access to NPIS applications. It makes it possible to inquire NPIS about persons, vehicles, documents, and things. The special so-called analytical system is also functioning and should be understood as the functionality of IT systems of the National Police Information System that performs the task of creating reports, analyzes, selection or compilation of information, including personal data, based on the selected system information processed in the NPIS database sets [15].

The widely used Municipal Crowd Management database is also referred as the NCCI (National Criminal Information Center), which is a register that stores all the data needed by law enforcement institutions. This massive database contains information from 18 sources, including the Border Guard, customs, social security, the Commission for Banking Supervision, the Securities and Exchange Commission. Because of its capacity and resources it is often broadly used. The POSIGRAF database (Police Graphical Information System) should be also mentioned. This system allows the registration as well as a presentation of photos of wanted or missing persons, unknown or unknown corpses, offenders, special characters photos (such as tattoos) or facial composites. This data previously scanned and entered into the database facilitate typing suspects, perpetrators, or identification of missing or deceased persons. A similar work is ascribed to a professional database AFIS (Automated Fingerprint Identification System), used for automatically matching one or many unknown fingerprints against a database of known and unknown prints identifying a person suspected of committing a crime. Unfortunately, its application is limited by tight legislation mentioned in the previous paragraph. It is said that "the lack of systematic database feeding by investigative service makes it obsolete and inadequate in relations to registered offenders." [10, pp. 12]. Despite the huge potential, therefore, the value of the base does not meet expectations but the reasons are stuck, as observed in previous section, outside the organization.

For the purposes of numerous police activities, a human intelligence (frequently abbreviated HUMINT) and open-source intelligence (OSINT) are used to collect information from human sources. It is intelligence where the term "open" refers to overt, publicly available sources (e.g. media) [1, pp. 143-144].

The Schengen Information System (SIS) is the latest generation system that consists of three main components: the central system, the national systems of states belonging to the Schengen area, and the infrastructure linking the central system with national. This secondgeneration system tended to maintain and distribute information on individuals and pieces of property of interest within the European Union ${ }^{4}$. "SIS II offers more options, such as the possibility of introducing biometric data (fingerprints and photographs), comes with new types of notifications (e.g. stolen planes, boats, containers or means of payment). It also offers the opportunity to associate with each different entries (e.g. on the person and the vehicle). European arrest warrants are in the system connected directly to the information on persons wanted for arrest and surrender or extradition, so that the responsible authorities may take more quickly and efficiently all the necessary actions. SIS II meets the strict requirements for data protection. Access is strictly limited only for national authorities responsible for border controls, police and customs authorities, the judiciary, offices issuing visas and dealing with the registration of vehicles." [4]. Polish police have begun in 2007 to connect to the second version of the system.

The Municipal Crowd Management also relies on PRIM (Police Record Mass Events) that includes information about the dates of these events, their organizers, sport clubs, fans, fun clubs, breaches of security and public order, disorderly conduct, the venues where mass sporting events are organized, moving of the participants of mass events, and additionally, relevant foreign institutions to cooperate.

Very functional is also ARTR application (Automatic Number Plate Registration) presented in an interview. It is a program that captures an image of cars in the moments when passing near one of the city's cameras. Then by entering the registration number of a specific car, it is possible to determine the exact day it was stored in a single location, in which direction was going, how fast, and in some situations the driver of the indicated car.

\footnotetext{
4 Everyone in this unit can see and make an adjustment to the data.
} 
The discussed department in this article is a place of continuous learning where the convictions of a constant need for development prevail. Technological and comprehensive thinking is clearly noticeable and the ability to embrace a holistic relationship between the participants in a particular project is also present. Conviction of its own imperfection, simultaneous desire for self-improvement, the pursuit of even better decisions and excellent command and constantly searching for opportunities to introduce more modern solutions and greater use of already owned contribute largely to a high degree of organizational maturity in the Municipal Crowd Management.

It is noticeable that there are so many conscious attempts to meet the requirements associated with market needs in the context of the creation of intelligent organizations and knowledge management in the Municipal Crowd Management. With the presented (important for this study) technological improvements and tools, we can create a well-functioning advanced network technology strongly supporting knowledge management in the police. Many of these solutions also support processes of acquiring information and processing them into useful and necessary knowledge, storing data, and protecting resources. Subsequently, the distribution takes place where the resources are subject to further processing and are transformed into a qualitatively different knowledge. The use of the available information and newly created knowledge develops and strengthens the experience and competence of the employees. It is impossible to draw a clear line between these systems and earlier discussed individual processes of knowledge management model in the police. It seems that it emerges from the specific character of the organization, which is precisely the police.

Specialists equipped with described techniques and technologies, tools, applications, and hardware may help to achieve much more than they perform but are often limited from outside by the regulatory framework, inadequate state funding, poor approach to the advantages of implementing some solutions or lack of formal authorizations for certain activities. It seems that the mere possession of tools and willingness to create something of value is insufficient and therefore, we should heighten awareness and put more emphasis on the agreement how to use this potential.

It can be concluded from the available legal opportunities and technological solutions that the police operations are achieving high effectiveness. We can observe the beginning of implementation of knowledge management system in terms of both philosophy and information and technology resources supporting operations of the entire unit. The Municipal Crowd Management takes a clear attempt to connect the hardness of management in hierarchical organizations with a soft concept, which is the management of knowledge.

In this place, it is worthwhile to bring in public opinion about discussed services that reflect the effectiveness and legitimacy undertaken by this department services. It should be recalled that the 2012 UEFA European Championship, commonly referred to as Euro 2012, was hosted by Poland, which was an enormous undertaking generating different types of threats. The performance of Municipal Crowd Management Department in association with other Departments during Euro 2012 has been rated very positively. According to research conducted by PBS, $84.2 \%$ of Poles believe that the organization of the tournament has contributed to the safety improvement and functioning of the police. Public opinion is a great motivator for continuous investment in development of national security, which should be secured by care and development of existing technological facilities to streamline police operations. Development of Knowledge Based Economyin Poland gives an example of adopting such measures that in consequence allows creation of egovernment, e-state, numerous improvements in terms of EU and global requirements, technological change, and social progress. It is important to take utmost advantage of the capabilities and competence of experienced people, financial resources, and legal opportunities; making efforts to modernize faster and create conditions for better and more pro-social functioning of public services, namely, the Police Forces.

\section{Summary}

In response to the market challenges and social change, it should be agreed that the implementation of the assumptions of the intelligent and knowledge-based organization in the public sector could raise their level of organizational maturity, effectiveness, and efficiency.

The key to the successful implementation of major features of this concept is the awareness of the employees as to the validity of the changes and the desire to make effort to modify certain rules, sometimes existing since many years. 
In the described case, we can see several places where the model of a knowledge-based organization is being used. Wherever there are financial possibilities and despite all constraints imposed by the specific nature of this organization a strong hierarchy, efforts are undertaken aiming to change this institution into a modern and open one, which will take care of the security and peace of society, while sustaining a high levels of prevention. This kind of institution will therefore become a more severe opponent in the ring of reality, both real and virtual for individuals, groups, or organizations that are deemed to constitute a threat to the stability and safety of citizens and the state.

\section{Bibliography}

[1] Częścik R. - PhD thesis: The use of mobile police position of command in the area of security and public order (Wykorzystanie policyjnego mobilnego stanowiska dowodzenia $w$ obszarze bezpieczeństwa i porzqdku publicznego). Gdynia 2011 (unpublished).

[2] Częścik R. - The possibility of using electronic tools for the purposes of identification, analysis, and visualization of the area of operational activities of police (Możliwości wykorzystania narzędzi elektronicznych na potrzeby rozpoznania, analizy terenu $i$ wizualizacji sytuacji operacyjnej $w$ działaniach policyjnych) [in] Acta Scientiarum Polonorum, Administratio Locorum, 12(1), Olsztyn 2013.

[3] Częścik R. - Boost of Information for the needs of command in activities of police (Zasilanie informacyjne na potrzeby dowodzenia $w$ działaniach policyjnych). Inaugural Lecture at the Faculty of Maritime Operations Command and the Naval Academy in Gdynia, Gdynia 2012, (unpublished).

[4] European Commission Press Release dated 9 April 2013, accessed August 2013,

http://europa.eu/rapid/press-release_IP-13309 pl.htm

[5] Probst G., Raub S., Romhardt K. - Knowledge management in organization (Zarzadzanie wie$d z q w$ organizacji). Oficyna Ekonomiczna, Kraków 2002.

[6] Grzybowski J., Jac A., Łukasiewicz A., Mielechow D., Piasecki T., Walczuk D. - The future of the organization, structures, processes and business environment. Terrified chameleon. Essays about the future management (Przysztość organizacji, struktur, procesów i otoczenia biznesu. Przerażony kameleon. Eseje o przyszłości zarzqdzania) (ed. P. Płoszajski). Fundacja Rozwoju Edukacji Menedżerskiej SGH, Warszawa 2005.

[7] Information of the Ministry of the Interior, accessed August 2013,

http://www.msw.gov.pl/portal/pl/2/10771/.

[8] Jashapara A. - Knowledge management. An integrated approach (Zarzadzanie wiedzq. Zintegrowane podejście). PWE, Warszawa 2006.

[9] Konończuk J. - The use of information systems to improve the efficiency of detection of threats, force planning and securing funds for the organization of mass events (Wykorzystanie systemów informatycznych $w$ poprawie efektywności rozpoznawania zagrożeń, planowania sit i środków przy organizacji zabezpieczania imprez masowych). Conference papers, Szczytno 2009.

[10] Kowalik A. - Creation, inspiration, innovation. Knowledge Management from concept to implementation [in] Management and development (Kreacja, inspiracja, innowacja. Zarzadzanie wiedza od pomystu do wdrożenia [w] Zarzqdzanie i rozwój), No 36 (5/2003).

[11] Krawczyńska A. - AFIS, which is the base used sparingly [in] POLICE 997 (AFIS, czyli baza skromnie wykorzystywana [w] POLICJA 997), No. 4(97), 2013.

[12] Modernization of Police (Modernizacja Policji) (ed. G. Rydlewski). Science and Industrial Consortium (Konsorcjum Naukowo - Przemysłowe) SECURUS, Warszawa 2013.

[13] Morawski M. - The problem of managing knowledge workers [in] Rreview of the organization. (Problematyka zarzadzania pracownikami wiedzy [w] Przeglad organizacji), No. 1/2003.

[14] Noszczyński T. - DNA vs. Law (Prawo kontra DNA). POLICJA 997, No. 4(97), 2013,

[15] Nycz M. - Generating knowledge for the enterprise; Methods and Techniques (Generowanie wiedzy dla przedsiębiorstwa; metody i techniki). AE Wrocław, Wrocław 2004. 
[16] Official Journal of the Police Headquarters, (Dziennik Urzędowy Komendy Głównej Policji). Warsaw, April 6, 2013, pos. 28, Decision of the Chief of Police No. 125.

[17] Olejniczak K. (ed.) - The learning organizations. The model for the public administration (Organizacje uczace się. Model dla administracji publiczej). Wydawnictwo Naukowe SCHOLAR, Warszawa 2012.

[18] Olejnik K., Maciejewski M. - Police Duty of Organizational Unit (Dyzurny Jednostki Organizacyjnej Policji). Wydawnictwo Szkoły Policji w Słupsku, Słupsk 2013.

[19] Schubring-Szafraniec M. - Proceedings of the first conference on the implementation of the SIPR project organized by the Centre for IT Projects in MSWiA, March 2011, Warszawa, accessed July 2013,

http://www.cpi.gov.pl/files/fck/File/konferencje/ SIPR_marzec_2011/I_Konf_SIPR_System_Wsp omagania_Dowodzenia_Policji.pdf.

[20] Senge M.P. - The fifth discipline (Piata Dyscyplina). Oficyna Ekonomiczna Oddział PWP, Warszawa 2006.
[21] Stewart T.A. - America's Secret Weapon [in] Business 2.0, December 2001.

[22] The official publication of the International Association of Chiefs of Police. (Oficjalna publikacja Międzynarodowego Stowarzyszenia Szefów Policji) (accessed July 2013), http://www.policechiefmagazine.org

[23] Walczak W. - Knowledge management and intellectual capital creation of a modern company (Zarzadzanie wiedza i kreowanie kapitatu intelektualnego wspótczesnego przedsiębiorstwa). Ementor, No. 2 (34)/2010 (accessed July 2013), http://www.e-mentor.edu.pl

[24] Website of the Indian journal published in English (accessed July 2013):

http://www.thehindu.com/todays-paper/tpnational/tp-karnataka/police-need-knowledge-oftechnology-says-igp/article4875374.ece.

[25] Website WASKO (accessed July 2013): http://www.wasko.pl.

[26] Zarzycki J. in review with Artur Kowalczyk: Training is essential (Szkolenia sq niezbędne). POLICJA 997, No. 4(97) 2013. 